\title{
Plant-available $P$ supply is not the main factor determining the benefit from arbuscular mycorrhiza to crop $P$ nutrition and growth in contrasting cropping systems
}

\author{
Helena Kahiluoto • Elise Ketoja • Mauritz Vestberg
}

Received: 18 November 2010 / Accepted: 22 June 2011 / Published online: 8 July 2011

(C) The Author(s) 2011. This article is published with open access at Springerlink.com

\begin{abstract}
Field studies have indicated that plantavailable $\mathrm{P}$ supply is the main determinant of the performance of arbuscular mycorrhiza (AM) of crops. Direct evidence is, however, weak. Our aim was to test the hypothesis that plant-available $\mathrm{P}$ is the main factor determining the benefit from $\mathrm{AM}$ to plant $\mathrm{P}$ uptake and growth in contrasting cropping systems. We compared a conventional system with full and half fertilisation rates and a low-input system with and without composting of residues. After 15 years, plant $\mathrm{P}$ response functions, with and without $\mathrm{AM}$, were determined in a bioassay. At equal plant availability of $\mathrm{P}$, the benefits from AM were similar to those at the $\mathrm{P}$ status in the field: The benefits were greater in the
\end{abstract}

Responsible Editor: Angela Hodge.

H. Kahiluoto $(\bowtie)$

MTT Agrifood Research Finland,

Plant Production Research,

Lönnrotinkatu 5,

50100 Mikkeli, Finland

e-mail: helena.kahiluoto@mtt.fi

E. Ketoja

MTT Agrifood Research Finland, Services Unit, 31600 Jokioinen, Finland

M. Vestberg

MTT Agrifood Research Finland,

Plant Production Research,

Antinniementie 1,

41330 Vihtavuori, Finland low-input system than in the conventional system, irrespective of the fertilisation rate but clearest with composting. This shows that differences between the systems in the benefit from AM to a particular crop genotype are not mainly due to differences in plantavailable $\mathrm{P}$. The results suggest also that differences in $\mathrm{P}$ pools, in growth-limiting factors such as $\mathrm{N}$ supply and in phytotoxicity to AMF hyphae play roles in determining the benefit. It is not likely that differences in AMF communities are important.

Keywords Cropping system · Fertilisation rate · Green manure $\cdot$ Composting $\cdot$ Phosphorus $(\mathrm{P})$ response function - Arbuscular mycorrhiza (AM)

\section{Introduction}

Arbuscular mycorrhiza (AM) acts as a major conduit in the principal elemental cycles (Fitter et al. 2011). It can increase host plant nutrient uptake and growth while suppressing non-mycorrhizal species (Cameron 2010). AM may especially enhance plant uptake of phosphorus $(\mathrm{P})$, nitrogen $(\mathrm{N})$ and micronutrients (Marschner and Dell 1994). Improved P nutrition is often the main benefit from AM to crop growth (Abbott and Robson 1984; Tinker and Nye 2000; Kahiluoto et al. 2009). Through promoted P recycling, AM contributes to reduced eutrophication and counteracts depletion of finite global P reserves (Gilbert 2009). These benefits from AM can be markedly fostered 
through appropriate management (Thingstrup et al. 1998; Kahiluoto et al. 2001; Gosling et al. 2006). Understanding the determinants of the benefits from $\mathrm{AM}$ in cropping systems is a precondition for such management.

The overall contribution of AM to plant P nutrition and growth is determined by the interaction among the host plant, the AM fungal partner, and the soil properties and other environmental factors. The impact of AM can be managed through all three of the partners. For example, the precondition for deriving a benefit from $\mathrm{AM}$ is that a crop genotype is selected, which responds positively to AM. Furthermore, the role of AMF hyphal networks in crop nutrition can be favoured through reduced tillage (Fitter et al. 2011). AMF species and clones differ in hyphal P uptake (Munkvold et al. 2004), in AM contribution to plant $\mathrm{P}$ uptake and growth (Smith et al. 2004) and in functional compatibility with certain crop genotypes in terms of $\mathrm{P}$ nutrition (Ravnskov and Jakobsen 1995; Burleigh et al. 2002). These differences play a role in management, because size (Ryan et al. 1994), species composition or diversity of AMF communities (Sylvia and Schenck 1983) and intraspecific functional diversity of AMF (Morton 1990) can be influenced by crop rotation and nutrient regimes (Johnson 1993; Scullion et al. 1998; Kahiluoto et al. 2000a).

Regarding the direct impact of soil $\mathrm{P}$ on $\mathrm{AM}$ functioning and benefits, high $\mathrm{P}$ availability in soil limits AM formation and may modify the growth habit (Sanders 1975) or reduce production of external hyphae and spore germination (de Miranda and Harris 1994). The benefit from additional $P$ and consequently from AM to crop growth is reduced at lower soil $\mathrm{P}$ concentrations than those which suppress colonisation or hyphal growth (Kahiluoto et al. 2001). This may lead to AM reducing crop growth (Graham and Eissenstat 1998; Kahiluoto et al. 2001; Ryan et al. 2005). Cropping systems influence the degree of benefit from AM to plant $\mathrm{P}$ nutrition and growth also through their effect on soil $\mathrm{P}$ pools, because the benefit from AM can vary among pools (Bolan et al. 1987; Hodge et al. 2001; Mäder et al. 2006; Kahiluoto et al. 2009). There are also factors that interfere with the impact of soil $\mathrm{P}$ on the benefit from AM. For example, the benefit from $\mathrm{AM}$ is usually higher if $\mathrm{P}$ limits growth, which depends on N supply also (Sylvia and Neal 1990; Kahiluoto et al. 2001).
Even if these interactions among the plant, soil and fungal partners of AM are known, their relative importance and management in cropping systems under field conditions is poorly understood (Ryan and Graham 2002; Ryan and Angus 2003; Plenchette et al. 2005). A frequent conclusion of studies with field soil is that in cropping systems the supply of plant-available $\mathrm{P}$ is the major factor that determines the functioning of AM (e.g., Thingstrup et al. 1998; Mäder et al. 2000; Ryan et al. 2000; Kahiluoto et al. 2001; Ryan and Graham 2002). The evidence for this conclusion is, however, insufficient. The reason is that the conclusion is based on, first, impacts on colonisation (Mäder et al. 2000; Ryan et al. 2000), while the rate of AMF colonisation and the benefit from AM to plant nutrition and growth are not directly related (Gange and Ayres 1999; Graham and Eissenstat 1998; Kahiluoto et al. 2001; Ryan et al. 2005). Second, the conclusion is based on studies where only P fertilisation rates varied (Thingstrup et al. 1998; Kahiluoto 2000; Kahiluoto et al. 2001; Dekkers and van der Werff 2001), or, third, it addresses cases where there is only indirect evidence of benefits from AM (e.g., Ryan and Ash 1999; Ryan et al. 2002). Therefore, direct evidence is required for the role that soil plantavailable $\mathrm{P}$ plays in determining the differences in AM contribution to crop nutrition and growth among contrasting cropping systems.

In the present study, we determined the role of the soil supply of plant-available $\mathrm{P}$ in the overall impact of cropping systems on AM, when not only the $\mathrm{P}$ fertilisation rate but also qualitative aspects of nutrient regimes vary. By determining the role of plantavailable $\mathrm{P}$, we also determined the importance of other factors for the benefit from AM to nutrition and growth of responsive crops. For this purpose, we created conditions of equal plant $\mathrm{P}$ availability using increasing dressings of soluble $\mathrm{P}$ in a bioassay with soil sampled from a long-term experiment in the field. The field experiment comprised a conventional system with full and half fertilisation rates and a low-input system including leguminous crops with and without composting of crop residues (Kahiluoto et al. 2009).

We identified the corresponding P response functions of the benefit from AM to plant $\mathrm{P}$ uptake and growth and of AMF colonisation (Abbott and Robson 1984; Bolan et al. 1987) using two responsive crop genotypes. We assessed this benefit through a com- 
parison between a plant with AM and a control with suppressed AM, to capture all the mechanisms within the impact of soil $\mathrm{P}$ on the interaction among the host plant, the AM fungal partner, and the soil. The present study is, to our knowledge, the first on $\mathrm{P}$ response functions of the benefit from AM to crops in contrasting cropping systems where not only $\mathrm{P}$ fertilisation rates vary. Moreover, this study is the first direct assessment of the role of soil plant-available $\mathrm{P}$ in the contribution of AM to plant performance in cropping systems.

The hypothesis tested was that plant-available $\mathrm{P}$ is the main factor determining the contribution of AM to $\mathrm{P}$ uptake and growth of a certain crop genotype in contrasting cropping systems.

\section{Materials and methods}

Field experiment

The experiment comprised three replicate blocks. A conventional and a low-input cropping system were randomly assigned to a pair of plots in each block. Two fertilisation rates were randomised to the two plots in the conventional cropping system. Also, two composting treatments, one with and the other without composting of recycled crop residues, were randomised to the two plots in the low-input system separately within each block. For all the four management systems three different starting points in the rotation were represented but only one per system was sampled in 1996 for the present study. The conventional cropping system relied on mineral NPK fertilisation, while the low-input cropping system was based on biological nitrogen fixation and enhanced nutrient recycling. The contrasting management systems were continuously used for 15 years.

The conventional cropping system had the following crop rotation: barley-barley-rye-oat-potato-oat. For oats and barley, N, P, and potassium (K) were applied before sowing at rates of 102 to 108,30 to 36 and 60 to $72 \mathrm{~kg} \mathrm{ha}^{-1} \mathrm{a}^{-1}$, respectively, depending on available commercial fertilisers, or half the stated rates. The rates for winter rye were 50,35 , and $85 \mathrm{~kg} \mathrm{ha}^{-1} \mathrm{a}^{-1}$, and for potato 70 to 80,100 , and $120 \mathrm{~kg} \mathrm{ha}^{-1} \mathrm{a}^{-1}$, respectively, or half these rates. For winter rye, $83 \mathrm{~kg} \mathrm{ha}^{-1} \mathrm{a}^{-1} \mathrm{~N}$ or half that rate was applied in the spring of the harvest year. In the crop rotation of the low-input cropping system, 1 year with barley was replaced by clover green manure under-sown with barley the previous year, and oats were cultivated mixed with pea (barleyclover-rye-oat + pea-potato-oat + pea). Straw, other crop residues and clover green manure were either directly incorporated into the soil in the autumn or, after heap composting, the following spring. The performance of the long-term field experiment with its management systems, initial soil quality parameters as well as results for yield, crop nutrient contents and soil quality were described in detail by Kahiluoto et al. (2009). The AMF spore densities were assessed and AMF were identified (Vestberg et al., accepted for publication).

\section{Bioassay}

The impact of the cropping systems with their nutrient regimes on $\mathrm{P}$ response of AM (Abbott and Robson 1984) and of AMF colonisation were studied in a bioassay previously developed (Kahiluoto et al. 2000b; Kahiluoto and Vestberg 2000). The bioassay, with a duration of 4 weeks, was shown to be a satisfactory gauge of the relative AM contribution to plant nutrition and growth in contrasting management systems, based on a comparison with the results of a field assay (Kahiluoto et al. 2000b; Kahiluoto and Vestberg 2000; Thingstrup et al. 2000). Soil for the bioassay was simultaneously collected from the 12 plots in the long-term field experiment (2 cropping systems $\times 2$ nutrient regimes $\times 3$ blocks). Soil was sampled in barley after either oat (the conventional cropping system) or oat+pea mixture (the low-input cropping system) as the preceding crop, after harvesting as samples composed of $15 \mathrm{sub}$-samples from each plot. Each of the three soil samples for the four management systems were divided between two test plant species (flax and red clover), and for both species among four $\mathrm{P}$ rates $(0,100,200$ and $400 \mathrm{mg}$ monocalcium phosphate $\mathrm{kg}^{-1}$ dry soil). Thus, there were 16 treatment combinations ( 2 cropping systems x 2 nutrient regimes x $4 \mathrm{P}$ rates) for both species.

For each treatment combination, a control with AM suppressed by the fungicide benomyl, at $20 \mathrm{mg}$ a. i. (kg soil at target moisture $)^{-1}$, was included and the pots with and without benomyl were paired. Benomyl has been shown to successfully prevent mycorrhizal hyphal growth and function, including in the present bioassay (Kahiluoto and Vestberg 2000; Thingstrup et al. 2000). Seven pre-germinated seeds per pot were 
sown and thinned to three seedlings per pot after emergence. The pairs of pots of flax and red clover were located at random and circulated daily within three blocks, which corresponded the blocks in the field experiment. The test plants were harvested and the plant and fungal analyses performed 4 weeks after sowing. The performance of the bioassay was described in further detail by Kahiluoto et al. (2009).

Analyses

Plant-available soil P was determined 1 week after P dressing and immediately before sowing using water extraction (van der Paauw 1971). Water-extractable P $\left(\mathrm{P}_{\mathrm{H} 2 \mathrm{O}}\right)$ predicts plant $\mathrm{P}$ availability in Finnish, naturally acid mineral soils relatively well and better than, for example, bicarbonate extraction, which was developed for calcareous soils (Olsen et al. 1960; Aura 1978; Hartikainen 1982). P responses were also considered at equal $\mathrm{P}$ uptake rates of the plant shoots with benomyl, because only the $\mathrm{P}$ uptake of a plant with suppressed AM exactly describes the plant availability of $\mathrm{P}$ with no contribution by AM.

A representative sample of the root system was cleaned and stained with methyl blue (Grace and Stribley 1991) and the percentage of colonised root length was determined using the gridline intersect method (Giovannetti and Mosse 1980). The shoots were cleaned and dried at $60^{\circ} \mathrm{C}$ and shoot dry weight was determined. Plant $\mathrm{P}$ concentrations were analysed by wet burning and inductively coupled plasma spectrometry (ICP) using an ARL 3580 OES system (Huang and Schulte 1985).

Modelling plant responses to water-extractable $\mathrm{P}$

\section{Shoot P uptake and dry weight}

To assess the role of plant-available $\mathrm{P}$ supply in the overall impact of the management systems on AM, P response functions were constructed for the four management systems with and without benomyltreatment of the soil. Data for the test plants clover and flax were analysed separately. To examine relationships between soil $\mathrm{P}_{\mathrm{H} 2 \mathrm{O}}$ rate and the two response variables, shoot $\mathrm{P}$ uptake and dry weight, scatter diagrams were drawn for the eight management system by benomyl treatment combinations on both test plants. The graphs revealed that the relation- ships and also the amount of variation in the observations depended on benomyl application and therefore the data for the two benomyl groups were modelled separately. Both response variables were mostly linearly related to soil $\mathrm{P}_{\mathrm{H} 2 \mathrm{O}}$ rate. The relation between shoot dry weight and soil $\mathrm{P}_{\mathrm{H} 2 \mathrm{O}}$ rate tended to be curvilinear only for the conventional cropping system with full fertilisation, for clover with and without benomyl application and for flax without benomyl. In the latter three groups a satisfactory approximation to each curvilinear $\mathrm{P}$ response function proved to be the second-order polynomial. Consequently, the models fitted to the data had the form:

$\mathrm{y}_{\mathrm{ij}}=\alpha+\beta \mathrm{x}_{\mathrm{ij}}+\gamma \mathrm{x}_{\mathrm{ij}}^{2}+\mathrm{b}_{\mathrm{i}}+\mathrm{e}_{\mathrm{ij}}$,

where $y_{i j}$ and $x_{i j}$ denote the values for shoot dry weight and soil $\mathrm{P}_{\mathrm{H} 2 \mathrm{O}}$ rate for pot $\mathrm{j}$ in block $\mathrm{i}$, respectively; $\alpha, \beta$ and $\gamma$ are the regression coefficients, $b_{i}$ is the random effect of block $i$, and $e_{i j}$ is the random error. The random effects $b_{i}$ and $e_{i j}$ are assumed to be independent, and within each term the effects are assumed to be independent and identically normally distributed with zero means and constant variances. Model (1) is a common polynomial regression model excluding the block effect which was included in the model because of the use of blocking in the experiment.

For the remaining data the relationship between soil $\mathrm{P}_{\mathrm{H} 2 \mathrm{O}}$ rate and the response ( $\mathrm{P}$ uptake or dry weight) was described by a regression line. The largest possible model in terms of the number of parameters (fitted separately to the data of the two benomyl groups) was of the following form:

$\mathrm{y}_{\mathrm{ijkl}}=\alpha_{\mathrm{kl}}+\beta_{\mathrm{kl}} \mathrm{x}_{\mathrm{ijk} \mathrm{l}}+\mathrm{b}_{\mathrm{i}}+\mathrm{d}_{\mathrm{ik}}+\mathrm{e}_{\mathrm{ijkl}}$,

where $y_{i j k 1}$ and $x_{i j k l}$ denote the values of the response variable and soil $\mathrm{P}_{\mathrm{H} 2 \mathrm{O}}$ rate for pot $\mathrm{j}$ of nutrient regime 1 within cropping system $\mathrm{k}$ in block $\mathrm{i}$, respectively; $\alpha_{\mathrm{k} 1}$ is the intercept and $\beta_{\mathrm{kl}}$ is the slope of the regression line for nutrient regime 1 in cropping system $\mathrm{k}$. The distributional assumptions of the random effects (block $\mathrm{b}_{\mathrm{i}}$, block-by-cropping system interaction $\mathrm{d}_{\mathrm{ik}}$, and random error $\mathrm{e}_{\mathrm{ijkl}}$ ) were similar to those for model (1). The mean part of the model $\mu_{\mathrm{kl}}=\alpha_{\mathrm{k} 1}+\beta_{\mathrm{kl}} \mathrm{x}_{\mathrm{ijk} 1}$ allows different intercepts $\alpha_{\mathrm{k} 1}$ and different slopes $\beta_{\mathrm{kl}}$ for each line of the four management systems. The slopes of the lines $\beta_{\mathrm{k} 1}$ represent the rates of increase in mean response $\left(\mu_{\mathrm{k} 1}\right)$ per unit increase in 
soil $\mathrm{P}_{\mathrm{H} 2 \mathrm{O}}$ rate. In model (2) each slope can be expressed through three parameters, an overall mean $(\beta)$, an effect due to cropping system $\left(\mathrm{C}_{\mathrm{k}}\right)$, and an effect due to nutrient regime in the cropping system $\left(T_{1(\mathrm{k})}\right)$ as follows: $\beta_{\mathrm{kl}}=\beta+\mathrm{C}_{\mathrm{k}}+\mathrm{T}_{1(\mathrm{k})}$. The dependence of the slope on cropping system and/or nutrient regime in the cropping system was tested by eliminating interaction terms $\mathrm{C}_{\mathrm{k}} \mathrm{x}_{\mathrm{ijkl}}$ and $\mathrm{T}_{1 \mathrm{k})} \mathrm{x}_{\mathrm{ijkl}}$ from the mean part of the model one at a time if they were not statistically significant, beginning with the term with the largest p-value. The statistical significances were determined by F-tests in which the method described by Kenward and Roger (1997) was used to calculate the denominator degrees of freedom. The models were fitted using the residual maximum likelihood (REML) estimation method. For both clover and flax observations of one pot pair (shown later in the figures) were excluded from the modelling because they were regarded as suspect measurements and would have had a pronounced effect on the results. The analyses were performed using the MIXED procedure of the SAS/STAT software version 9.2 (Littell et al. 2006).

\section{AMF colonisation}

For each management system without benomyl application, the relationship between soil $\mathrm{P}_{\mathrm{H} 2 \mathrm{O}}$ rate and AMF colonisation was described by a logistic regression model, which is a common model for counted data in the form of proportions and was suggested for the analysis of arbuscular mycorrhizal colonisation data by Alvarez-Santiago et al. (1996). In the models for clover and flax, the distribution of $y_{i j k l}$, the number of infected roots out of 100 intersections for pot $\mathrm{j}$ of nutrient regime 1 in cropping system $\mathrm{k}$ and block i, was assumed to be binomial (conditional on the random effects) with parameters $\mathrm{n}$ and $\pi_{\mathrm{ijk}}$, where $\mathrm{n}$ is the total number of intersections (100) and $\pi_{\mathrm{ijkl}}$ is the probability (proportion) of occurrence of mycorrhizal colonisation of a root segment. The models, written in terms of $\pi_{\mathrm{ijk}}$, had the following form:

$\log \left[\pi_{\mathrm{ijkl}} /\left(1-\pi_{\mathrm{ijkl}}\right)\right]=\alpha_{\mathrm{kl}}+\beta_{\mathrm{kl}} \mathrm{x}_{\mathrm{ijk} \mathrm{l}}+\mathrm{b}_{\mathrm{i}}+\mathrm{d}_{\mathrm{ik}}$,

where the random effects $\left(b_{i}, d_{i k}\right)$ and their distributional assumptions are similar to those for model (2) above. The fixed effects part, $\alpha_{\mathrm{kl}}+\beta_{\mathrm{kl}} \mathrm{x}_{\mathrm{ijk} \mathrm{k}}$, allows different models for the four management systems which were used to explain the results of $\mathrm{P}$ uptake and dry weight. The mean proportion of AMF colonisation for each management system $\left(\pi_{\mathrm{kl}}\right)$ can be solved from Eq. (3) as follows: $\pi_{\mathrm{kl}}=\left[1+\exp \left(-\alpha_{\mathrm{kl}}-\beta_{\mathrm{kl}} \mathrm{x}_{\mathrm{ijk} 1}\right)\right]^{-1}$. The parameters for the models were estimated by using maximum likelihood estimation based on adaptive Gaussian quadrature (Molenberghs and Verbeke 2005). The analyses were performed by the GLIMMIX procedure of the SAS/STAT software, version 9.2.

\section{Results}

Final models for plant responses to water-extractable $\mathrm{P}$

\section{Clover}

A regression line adequately described the positive relationship between the soil concentration of $\mathrm{P}_{\mathrm{H} 2 \mathrm{O}}$ and shoot $\mathrm{P}$ uptake for all four management systems with and without benomyl application. For the benomyltreated soil the final model included different slopes and different intercepts for the four management systems (Fig. 1a). The significance levels corresponding to the interactions in the slopes between soil $\mathrm{P}_{\mathrm{H} 2 \mathrm{O}}$ rate and cropping system and between soil $\mathrm{P}_{\mathrm{H} 2 \mathrm{O}}$ rate and nutrient regime within cropping system were 0.04 and 0.01 . The latter interaction indicates that either the slopes for full and half fertilisation in the conventional cropping system differ and/or those for with and without composting in the low-input system differ. The $p$ values for the differences in the slopes between full and half fertilisation and between the treatments with and without composting were 0.01 and 0.03 , respectively. Without benomyl application only the interaction between soil $\mathrm{P}_{\mathrm{H} 2 \mathrm{O}}$ rate and nutrient regime in the cropping system tended to be statistically significant $(p=0.05)$. This was mainly due to full fertilisation, the slope for which was smaller than those for the other management systems. Therefore, a model including parallel lines (slope $=0.026)$ for management systems other than full fertilisation (slope $=0.013$ ) was chosen as representing the data best. The lines are presented in Fig. 2a-d together with the lines for the benomyl-treated soil and the scatter diagrams of the data.

A regression line also proved to be a suitable model for the relationship between soil concentration of $\mathrm{P}_{\mathrm{H} 2 \mathrm{O}}$ and shoot dry weight, with the exception of full fertilisation in the conventional cropping system, 
Fig. 1 P response functions for $\mathrm{P}$ nutrition in contrasting management systems with suppressed AM $(\widehat{\mu}=$ the estimated mean response)

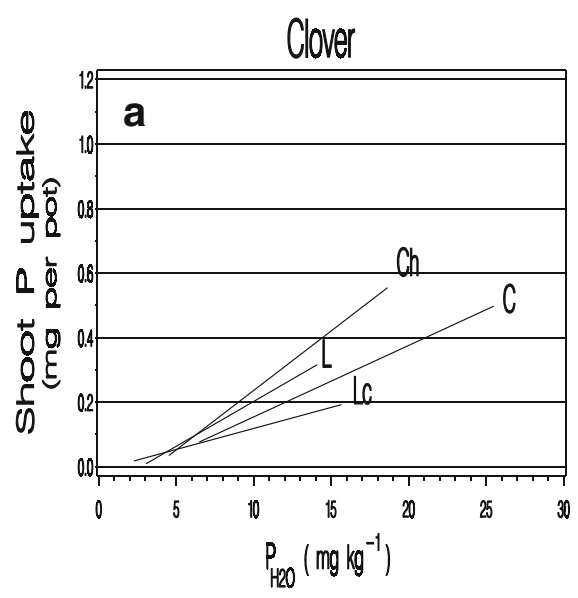

Conventional, full fertilisation ( C ) : $\hat{\mu}=-0.068+0.022 x$

Conventional, half fertilisation (Ch) : $\hat{\mu}=-0.132+0.037 x$

Low-input, no composting ( $L): \hat{\mu}=-0.076+0.028 x$

Low-input, $\quad$ composting $(\mathrm{LC}): \hat{\mu}=-0.011+0.013 x$

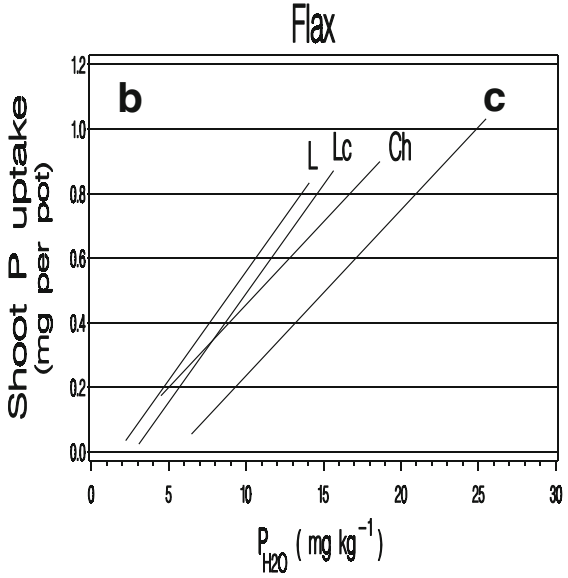

Conventional, full fertilisation (C ) : $\hat{\mu}=-0.279+0.051 x$ Conventional, half fertilisation ( Ch ) : $\hat{\mu}=-0.059+0.051 \mathrm{x}$ Low-input, no composing (L ) : $\hat{\mu}=-0.117+0.067 x$ Low-input, $\quad$ composing (LC) : $\hat{\mu}=-0.185+0.067 x$ for which the relation was curvilinear (Fig. 2e). Furthermore, for both benomyl-treated and untreated soils the slopes of the lines were dependent neither on cropping system $(p>0.36)$ nor on nutrient regime within the cropping system $(p>0.16)$. Consequently, parallel lines were fitted for the three management systems in the two benomyl groups (slopes 4.589 and 5.349 with and without benomyl, respectively, Fig. 2f-h).

The fitted $\mathrm{P}$ response functions for AMF colonisation are presented in Fig. $2 \mathrm{i}-1$ with the scatter diagrams of the data. Only insignificant mycorrhizal colonisation $(0$ or $1 \%$ in most pots, $2-4 \%$ in some pots and in one pot $5 \%$ ) was found in plants grown in benomyl-treated field soil.

Flax

Modelling the relationship between soil concentration of $\mathrm{P}_{\mathrm{H} 2 \mathrm{O}}$ and shoot $\mathrm{P}$ uptake for the benomyl-treated soil using regression lines showed that the slopes of the lines depended on cropping system $(p=0.05)$, but not on nutrient regime within the cropping system $(p=$ 0.17 , Fig. 1b). Without benomyl application the slopes depended on both factors ( $p=0.01$ and $p=0.02$ for soil $\mathrm{P}_{\mathrm{H} 2 \mathrm{O}}$-by-cropping system and soil $\mathrm{P}_{\mathrm{H} 2 \mathrm{O}}$-by-nutrient regime interaction, respectively). However, as with clover, this was mainly due to the slope for full fertilisation being smaller than the slopes for the other management systems. Hence, a simpler model with just two different slopes, one for full fertilisation (slope= 0.017) and the other for the remaining management systems (slope $=0.045$ ), adequately fitted the data (Fig. 3a-d).

With benomyl, the relation between soil $\mathrm{P}_{\mathrm{H} 2 \mathrm{O}}$ and shoot dry weight was linear in all groups including the conventional cropping system with full fertilisation. As was also seen for shoot $\mathrm{P}$ uptake, the slopes of the lines did not depend on nutrient regime $(p=$ $0.34)$, but depended on cropping system $(p<0.001$, slopes 6.284 and 12.538 for conventional and lowinput cropping system, respectively, Fig. 3e-h). Without benomyl, the linear relations for the groups other than full fertilisation were independent of both cropping system $(p=0.73)$ and nutrient regime $(p=$ 0.96 ), indicating parallel lines for the three management systems $($ slope $=5.832$, Fig. $3 \mathrm{e}-\mathrm{h}$ ).

The fitted $\mathrm{P}$ response functions for AMF colonisation are presented in Fig. 3i-1 together with the scatter diagrams of the data. Only insignificant mycorrhizal colonisation (mainly $0 \%$, in some pots $1 \%$ and in one pot $4 \%$ ) was found in plants grown in benomyltreated field soil.

Figure 1 shows that $\mathrm{P}$ uptakes of non-mycorrhizal plants may vary among the management systems even 
Conventional: full fertilisation
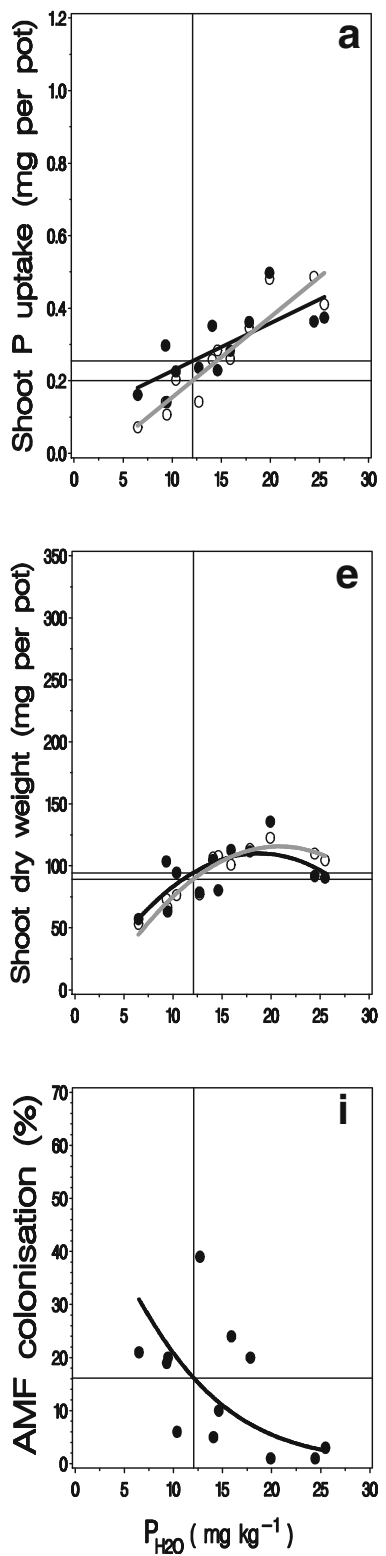

Conventional: half fertilisation
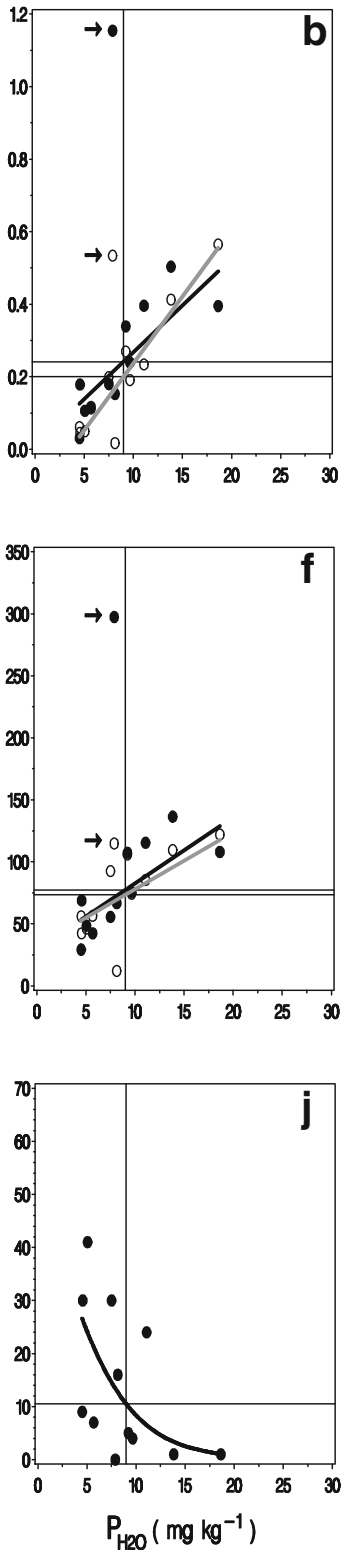

Fig. 2 Test plant red clover. $\mathrm{P}$ response functions for $\mathrm{P}$ nutrition and growth with AM (black line) and with suppressed AM (gray line) and for AMF colonisation in contrasting management systems. The observations with and without AM are denoted by filled and open circles, respectively. The vertical reference lines in all the figures correspond to shoot $\mathrm{P}$ uptake of $0.2 \mathrm{mg}$ per pot without AM, and the contributions of AM to

if the concentration of water-extractable $\mathrm{P}$ in soil is the same (e.g. $10 \mathrm{mg} \mathrm{P}_{\mathrm{H} 2 \mathrm{O}}$ per $\mathrm{kg}$ ). This indicates that besides soil concentration of $\mathrm{P}_{\mathrm{H} 2 \mathrm{O}}$ and contribution by $\mathrm{AM}$, plant $\mathrm{P}$ uptake depends on other soil variables
Low-input: no composting
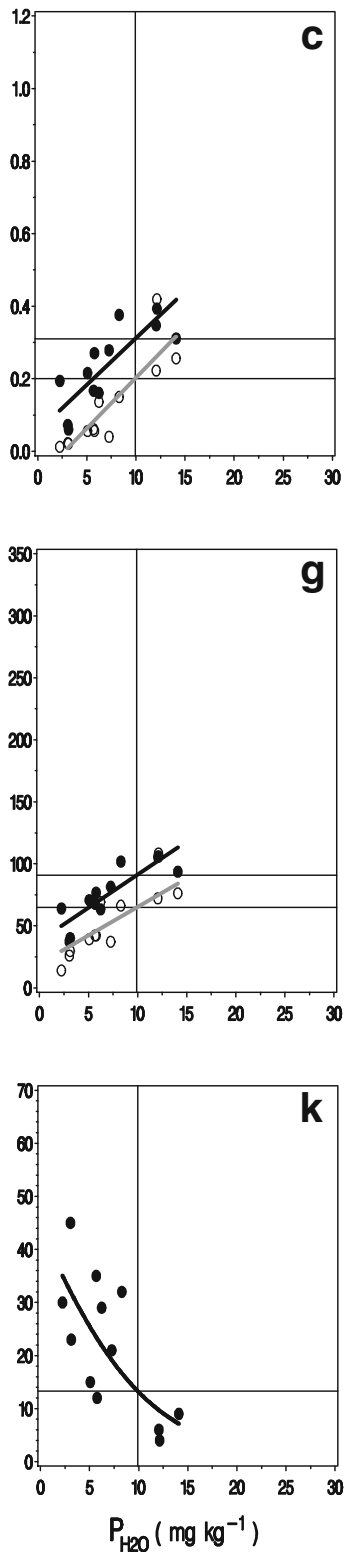

Low-input: composting
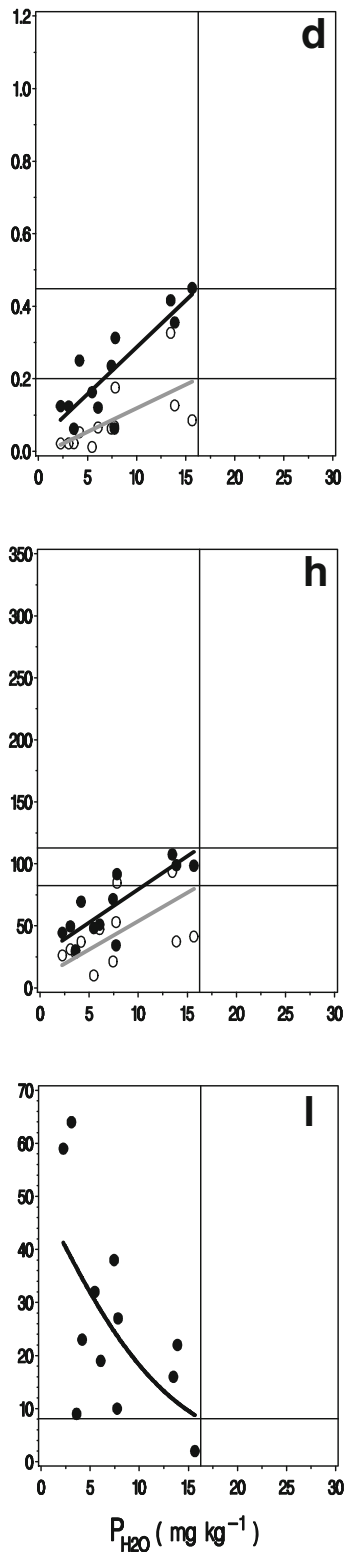

plant $\mathrm{P}$ uptake and growth at this $\mathrm{P}$ uptake rate are shown as the distances between the two horizontal lines which intercept the vertical axes. The models of both benomyl groups were based on data from which the discrepant observation for the conventional cropping system with half fertilisation (marked with arrows) was excluded

(e.g. P pool, soil $\mathrm{N}$ supply) which may interact differently with the management systems. To assess the effects of these variables on the differences in $\mathrm{P}$ response of AM between the management systems, 
Conventional: full fertlisation
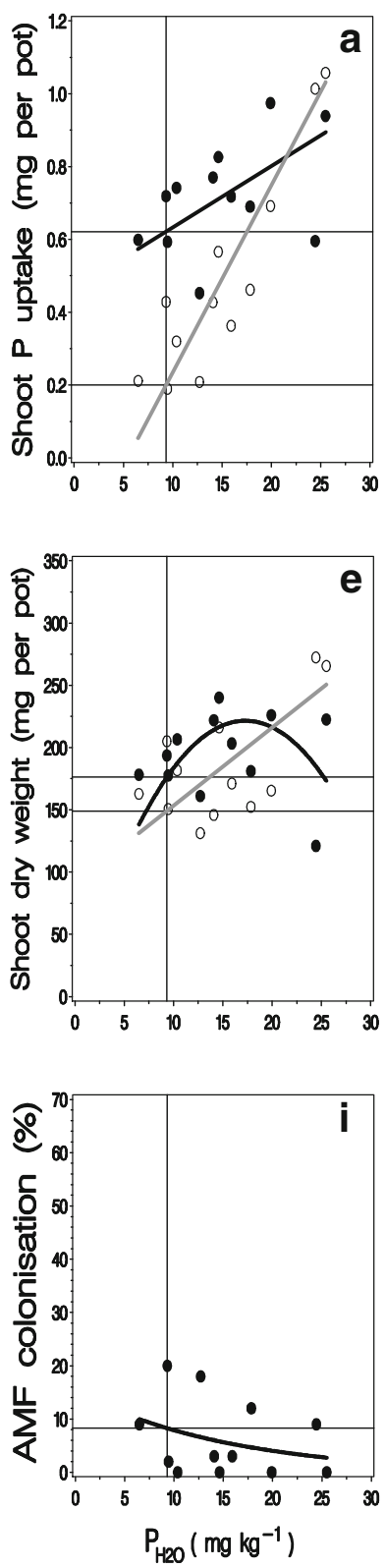

Conventional: half fertilisation
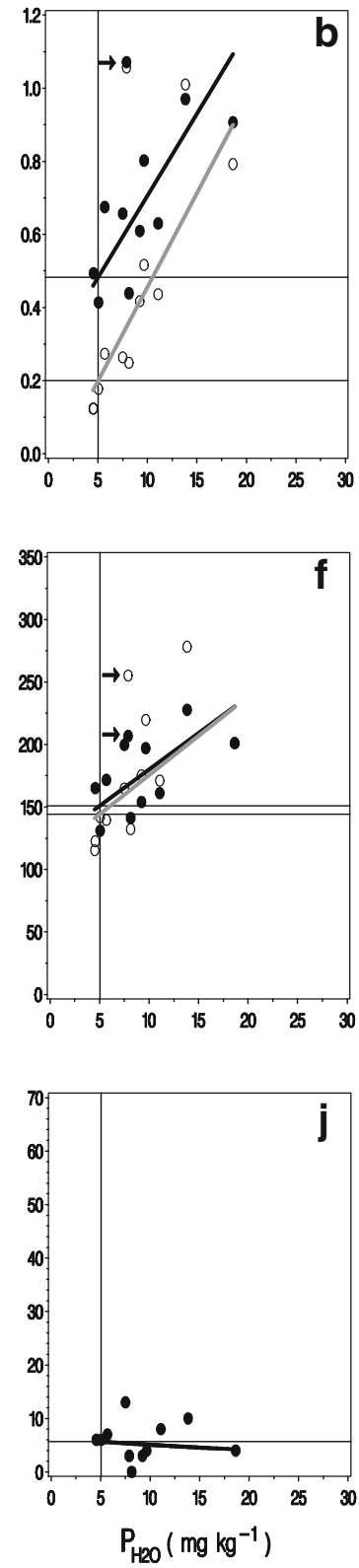

Fig. 3 Test plant flax. P response functions for $\mathrm{P}$ nutrition and growth with AM (black line) and with suppressed AM (gray line) and for AMF colonisation in contrasting management systems. The observations with and without AM are denoted by filled and open circles, respectively. The vertical reference lines in all the figures correspond to shoot $\mathrm{P}$ uptake of $0.2 \mathrm{mg}$ per pot

the comparisons are done below both at equal $\mathrm{P}$ uptake rates of non-mycorrhizal plants and at equal soil concentrations of $\mathrm{P}_{\mathrm{H} 2 \mathrm{O}}$. The former comparisons consist of the differences in shoot $\mathrm{P}$ uptake and growth between the mycorrhizal and non-mycorrhizal

Low-input: no composting

Low-input: composting
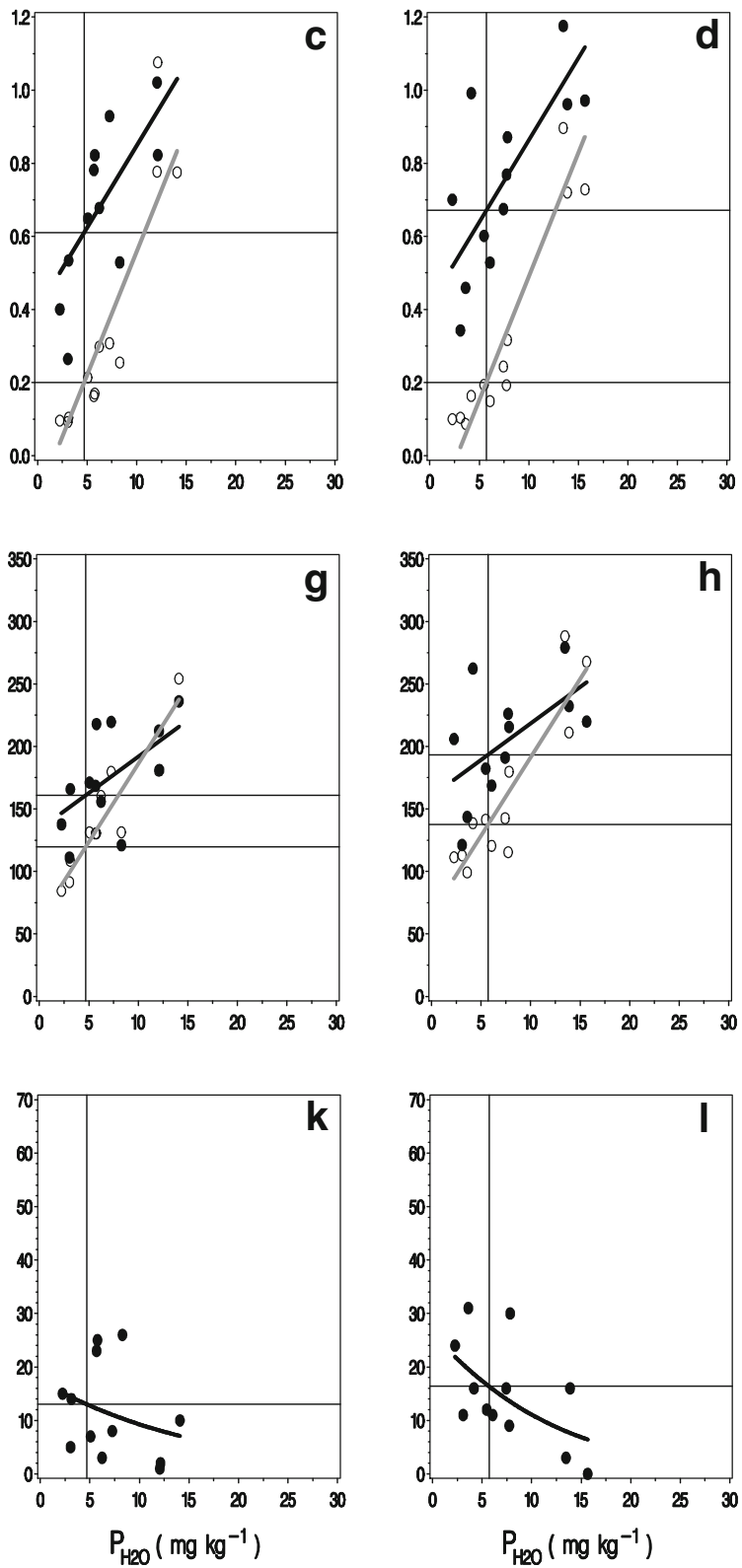

without AM, and the contributions of AM to plant P uptake and growth at this $\mathrm{P}$ uptake rate are shown as the distances between the two horizontal lines which intercept the vertical axes. The models of both benomyl groups were based on data from which the discrepant observation for the conventional cropping system with half fertilisation (marked with arrows) was excluded

plants when the effects of the interacting variables are eliminated from the responses of the non-mycorrhizal plants. In the latter comparisons the responses of both mycorrhizal and non-mycorrhizal plants include the effects of the interacting variables. 
Differences in P response of AM

among the management systems

There were differences among the management systems in the fitted $\mathrm{P}$ response functions with and without benomyl and thus in the contribution of AM to shoot $\mathrm{P}$ uptake and growth at equal plant $\mathrm{P}$ availability. In most cases AM contributions at equal shoot $\mathrm{P}$ uptake rates of the control with suppressed AM (e.g. at $0.2 \mathrm{mg}$ per pot, Figs. $2 \mathrm{a}-\mathrm{h}, 3 \mathrm{a}-\mathrm{h}$ ) were quantitatively only slightly different from AM contributions at equal soil concentrations of $\mathrm{P}_{\mathrm{H} 2 \mathrm{O}}$. However, the non-parallelism of the $\mathrm{P}$ response functions of plants grown with and without benomyl indicated that there can be exceptions. For clover, for example, at a soil $\mathrm{P}_{\mathrm{H} 2 \mathrm{O}}$ concentration of $10 \mathrm{mg}$ per $\mathrm{kg}$, which for the low-input system with no composting corresponds to a $\mathrm{P}$ uptake rate of $0.2 \mathrm{mg}$ per pot with benomyl (Fig. 2c), the AM contribution to shoot $\mathrm{P}$ uptake would be higher with full fertilisation and lower with composting than if considered at the non-mycorrhizal P uptake rate of $0.2 \mathrm{mg}$ (Fig. 2a, d). Similarly, for flax the AM contribution depends on whether it is considered at equal $\mathrm{P}$ uptake rates with suppressed $\mathrm{AM}$ or at equal soil $\mathrm{P}_{\mathrm{H} 2 \mathrm{O}}$ rates (e.g. at $5 \mathrm{mg}$ $\mathrm{P}_{\mathrm{H} 2 \mathrm{O}}$ per kg, Fig. $3 \mathrm{a}-\mathrm{h}$ ). This was especially true for full fertilisation. In addition, colonisation of clover was, at equal soil $\mathrm{P}_{\mathrm{H} 2 \mathrm{O}}$ rates, only slightly higher with full fertilisation than with composting, while at an equal $\mathrm{P}$ uptake rate with benomyl the difference was clear (Fig. 2i, 1). At equal soil $\mathrm{P}_{\mathrm{H} 2 \mathrm{O}}$ rates, colonisation was higher with composting than without composting, but at the $\mathrm{P}$ uptake rate of $0.2 \mathrm{mg}$ per pot with benomyl, for example, colonisation was higher without composting (Fig. 2i, k).

\section{Clover}

The AM contribution to shoot $\mathrm{P}$ uptake and growth was consequently clearly higher in the low-input system than in the conventional system (where it scarcely registered) irrespective of the fertilisation rate, at equal soil concentrations of $\mathrm{P}_{\mathrm{H} 2 \mathrm{O}}$ (e.g., at 6 or $10 \mathrm{mg} \mathrm{P}_{\mathrm{H} 2 \mathrm{O}}$ per $\mathrm{kg}$ ) and at equal $\mathrm{P}$ uptake rates of the control with $\mathrm{AM}$ suppressed by benomyl (e.g., at 0.1 or $0.2 \mathrm{mg}$ per pot) (Fig. 2a-h). In the low-input system, as opposed to the conventional system, the AM contribution to $\mathrm{P}$ uptake did not decline as the soil $\mathrm{P}_{\mathrm{H} 2 \mathrm{O}}$ concentrations increased in the studied range. With composting it even tended to increase. At equal $\mathrm{P}$ uptake rates with suppressed
AM, halving fertilisation in the conventional system resulted in a slight decline in AM contribution to $\mathrm{P}$ uptake (Fig. 2a, b) and growth (Fig. 2e, f) compared to full fertilisation. AM was more effective in the system with composting (Fig. 2d, h) than with no composting (Fig. 2c, g), especially at the upper end of the range of $\mathrm{P}_{\mathrm{H} 2 \mathrm{O}}$ concentrations and $\mathrm{P}$ uptake with suppressed AM. Regarding AMF colonisation, no clear difference emerged between half fertilisation and the low-input system (Fig. 2j, k, 1). Instead, half fertilisation resulted in lower colonisation than full fertilisation at equal $\mathrm{P}$ uptake rates with suppressed AM (Fig. 2i, j). Colonisation was higher without composting than with it (Fig. 2k, 1), whereas it was higher with composting if considered at equal soil $\mathrm{P}_{\mathrm{H} 2 \mathrm{O}}$ concentrations.

\section{Flax}

For flax, the conventional and the low-input system differed less in AM contribution to shoot $\mathrm{P}$ uptake and growth at equal plant $\mathrm{P}$ availability than they did for clover. A decline in the AM contribution occurred along with the increase in the soil $\mathrm{P}_{\mathrm{H} 2 \mathrm{O}}$ concentration in the studied range in all the systems, but for $\mathrm{P}$ uptake it was most apparent with full fertilisation (Fig. 3a-d). At the higher end of plant $\mathrm{P}$ availability (e.g., at $14 \mathrm{mg} \mathrm{P}_{\mathrm{H} 2 \mathrm{O}}$ per $\mathrm{kg}$ soil or at $0.6 \mathrm{mg} \mathrm{P}$ in shoot per pot with benomyl) the AM contribution to growth in the low-input system especially with no composting (Fig. 3c, g) was smaller than with full fertilisation (Fig. 3a, e). The tendency towards a higher AM contribution to $\mathrm{P}$ uptake and growth with full rather than half fertilisation at the lower $\mathrm{P}_{\mathrm{H} 2 \mathrm{O}}$ rates was clearer for flax (Fig. 3a, b, e, f) than for clover $(2 \mathrm{a}, \mathrm{b}, \mathrm{e}, \mathrm{f})$. In the low-input system the benefit from composting for the AM contribution to growth (Fig. 3g, h) was also clearer than for clover (Fig. 2g, h). Further, a notable difference in AMF colonisation in favour of the low-input system emerged at equal $\mathrm{P}$ uptake rates with suppressed AM. In contrast to clover, the difference in colonisation between full and half fertilisation was negligible at an equal $\mathrm{P}$ uptake rate with benomyl (Fig. 3i, j).

\section{Discussion}

Our findings suggest that the differences among the management systems regarding the contribution of 
AM to crop P uptake and growth are not mainly due to differences in plant-available $\mathrm{P}$ supply, but rather that other, more important determining factors are involved. Thus, the data gave no support to our hypothesis.

Methods and generalisation

The management systems studied exemplify specialised crop production, and thus the dominant type of cropping systems in northern Europe and in Europe more generally. The main constraint to generalising these findings is the location of the long-term experiment on a single field site. It leads to a limited representation regarding the initial AMF community and other edaphoclimatic conditions. The initial concentration of extractable $\mathrm{P}$ in the soil was relatively low, which tends to reduce differences in AM among the studied management systems and reduce the role $\mathrm{P}$ availability to plants plays in determining the differences in AM. Since growth increased linearly with increased P supply, P was a growth limiting factor in the systems. An exception was the conventional full fertilisation. In accordance with this, Kahiluoto et al. (2009) reported higher contents of sparingly soluble Al- and Fe-bound P in the conventional system with full fertilisation than in the other management systems due to the cumulative effects of fertilisation. Regarding flax with suppressed AM, P availability limited growth even under full fertilisation. AM has a better access to sparingly available inorganic (Bolan et al. 1987) and organic (Kahiluoto and Vestberg 1998; Hodge et al. 2001) P pools than plants with suppressed AM.

Differences in nutrient intensity represent a major interfering factor in comparisons of management systems since nutrient intensity may override, and interact with, all the other differences. Nutrient intensity, especially P intensity (Schofield 1955), has also a major impact on AM contribution to plant performance. We avoided this type of interference through the creation of $\mathrm{P}$ response functions. The $\mathrm{P}$ intensity, indicated here by the soil concentration of water-extractable $\mathrm{P}$, does not, however, precisely coincide with $\mathrm{P}$ availability, even to non-mycorrhizal plants. A P-test at best only provides a relative estimate of the soil P-status, but no direct information on the crop response to added P (Sibbesen 1983). For example differences in $\mathrm{P}$ pools (and thus $\mathrm{P}$ capacity) among the management systems may interfere with the assessment of $\mathrm{P}$ availability to plants, because the ratio between the extractable and plant-available $\mathrm{P}$ may vary among the $\mathrm{P}$ pools (intensity-capacity ratio) (Hartikainen 1982). Water extraction has for long been established as a method which provides a high correlation between the extractable soil phosphate and the plant response, not affected by soil properties and origins (van der Paauw 1971) also for Finnish field soils (Hartikainen 1982). Sibbesen ranked in his review (1983) water and sodium bicarbonate methods immediately after the anion exchange resin method in predicting plant $\mathrm{P}$ uptake from soil, and better than all the 'acid' methods investigated.

We demonstrated that $\mathrm{P}$ uptake by flax with benomyl was notably reduced in the conventional cropping system with full fertilisation in comparison with the other management systems at an equal concentration of water-extractable $\mathrm{P}$ through the studied range of $\mathrm{P}$ availability. The same was true with composting for clover, apart from the lowest end of the studied range. With full fertilisation a greater share of the water-extractable $\mathrm{P}$ seemed to originate from the accumulated fertiliser $P$ relative to the freshly added $P$ than under other management systems. Water-extractability of the cumulated $\mathrm{P}$ clearly exceeded its availability to flax with no AM in the bioassay. A similar impact on soil $\mathrm{P}$ pools by composting is possible (Fliessbach et al. 2007), even if not detected (Kahiluoto et al. 2009). The difference in $\mathrm{N}$ supply among the management systems and its effect on $\mathrm{C}$ limitation to plants does not explain the difference in $\mathrm{P}$ uptake by flax with benomyl with full fertilisation in comparison with the other management systems at an equal rate of water-extractable $\mathrm{P}$.

Consequently, consideration of $\mathrm{P}$ response at an equal rate of extractable $\mathrm{P}$ is not sufficient when comparing treatments that could have an impact on $\mathrm{P}$ pools or on $\mathrm{N}$ supply, even if such comparisons are often made. When comparing plant $\mathrm{P}$ availability of contrasting management systems, consideration of the $\mathrm{AM}$ contribution at an equal rate of $\mathrm{P}$ uptake of the control with suppressed AM was shown to be important. It is important also because $\mathrm{P}$ availability limits AM formation mainly through elevated plant $\mathrm{P}$ concentration (Sanders 1975). Equal rates of nonmycorrhizal P uptake allow valid comparisons and ensure relevance through taking into account the factors interacting with crop $\mathrm{P}$ uptake in the management systems. Ensuring validity by applying $\mathrm{N}$ and 
other nutrients in excess, as is often recommended, creates artefacts (Kahiluoto 2000). Considering the differences in plant $\mathrm{P}$ responses to $\mathrm{AM}$ both at equal $\mathrm{P}$ uptake rates with benomyl and at an equal rate of extractable $\mathrm{P}$ also helps conclusions to be drawn on the mechanisms underlying the differences in $\mathrm{P}$ response of AM among the management systems. The reason is that the factors that cause differences between these two assessments may also affect differences in $\mathrm{P}$ responses by AM among the management systems.

The bioassay used was previously shown to find differences in the AM contribution to plant nutrition and growth that paralleled those found in the field, with no confounding effects on pathogens or other soil microbes or nutrients (Kahiluoto et al. 2000b; Kahiluoto and Vestberg 2000). Benomyl successfully inhibited AMF colonisation. The use of two test plant species, which differ in their responsiveness to $\mathrm{P}$ and $\mathrm{AM}$, increases the generality of the results.

Factors underlying the impact of management systems on AM

The differences in the AM contribution to plant $\mathrm{P}$ uptake and growth among the management systems were not due to differences in plant-available P. This was shown by the fact that there were differences in the AM contribution to plant $\mathrm{P}$ uptake and growth among the systems when compared at equal plant $\mathrm{P}$ availability. Furthermore, the differences at equal plant $\mathrm{P}$ availability were similar to the differences seen at the lowest soil supply of plant-available P of the studied range, i.e., at the $\mathrm{P}$ status of the systems in the field. This was the case even if growth increase by AM apparently derived mainly from the contribution to plant nutrition, especially to $\mathrm{P}$ uptake (Kahiluoto et al. 2009).

The AM contribution to plant $\mathrm{P}$ uptake and growth at equal plant availability of $\mathrm{P}$ was greater in the lowinput than in the conventional cropping system even at the halved fertilisation rate. This was most clear with composting, and for P uptake of flax only true with it. In the case of flax, for which colonization rates were generally lower than for clover, the higher colonisation rates approximately coincided with higher AM contribution to plant performance. For clover, there were small differences in colonisation among the systems and the colonisation rates were obviously high enough for the maximum benefit in all the cases, and so colonisation rates did not always coincide with the benefits from AM to plants. Neither would the difference in $\mathrm{N}$ and the consequent difference in $\mathrm{C}$ supply explain these differences in the benefit from AM to clover: the $\mathrm{N}$ supply (Kahiluoto et al. 2009) and thus P limitation at equal plant availability of P (Sylvia and Neal 1990; Kahiluoto et al. 2001), was higher in the conventional than in the low-input system, while the benefit from AM was relatively lower in the conventional system.

The reason for higher colonisation of flax and a higher AM contribution to flax and clover nutrition and growth at equal plant availability of $\mathrm{P}$ in the lowinput system could principally be a difference in the AMF communities. Essential differences in spore density or in species composition among the management systems were, however, not observed (Vestberg et al. 2011). Neither was there evidence of inter- or intraspecific (Morton 1990) functional differences in the AMF communities among the management systems in a bioassay (Kahiluoto, unpublished results). The bioassay implied re- and cross-inoculation of the microbial communities from the treatments of the same field experiment to sterilised field soils. A reason to lack of differences in the AMF communities may be transport of propagules from other treatments and from the environment by, e.g., machines, wind or animals. Contrary results have been obtained in some other studies comparing farm pairs (Scullion et al. 1998) or fertilisation rates only (Johnson 1993; Kahiluoto et al. 2000a). A difference in other soil properties, e.g., in the nutrient pools (Mäder et al. 2006; Hartikainen et al. 2006, Kahiluoto et al. 2009) and the benefit from AM in the utilisation of these pools (Bolan et al. 1987; Hodge et al. 2001) could play a role.

The greater AM contribution to plant $\mathrm{P}$ uptake and growth with full rather than half fertilisation on flax and a similar or no difference on clover were likely due to AM providing a better access to the superior pool of sparingly soluble residual $\mathrm{P}$ from cumulative fertilisation by AM than plants with suppressed AM had. The possibility that unlimited N (thus with less effect on clover) or by higher AMF species diversity with full fertilisation (Vestberg et al. 2011) play roles cannot be excluded. The increased contribution can not be explained by the small difference in colonisation. With half fertilisation, the notable AM contribution to $\mathrm{P}$ uptake at the higher end of the $\mathrm{P}$ availability range was not reflected in growth, as no benefit 
occurred with abundant plant-available $\mathrm{P}$ and limiting $\mathrm{N}$ supply.

The reduced AM contribution to P uptake with no composting in comparison to composting in the lowinput cropping system was for clover not explained by the difference in colonisation at equal $\mathrm{P}$ uptake with suppressed AM. It is probably due to a slight phytotoxic effect from the decomposition of crop residues in the soil, especially with respect to the growth and functioning of the extraradical hyphae. Composting of the crop residues before incorporation can hinder this phytotoxic effect (Mosse et al. 1981; De Bertoldi et al. 1983). A similar but a more marked effect was reported by Kahiluoto et al. (2009) after incorporation of clover green manure, while the current bioassay was performed at the rotation stage after incorporation of oat and pea straw. A higher share of extraradical to intraradical hyphal development (Sanders 1975) could also explain the reduced percentage colonisation with composting at an equal level of non-mycorrhizal $\mathrm{P}$ uptake of clover. In accordance with this, the AM contribution to $\mathrm{P}$ uptake was almost abolished in terms of growth on clover, but not on flax with its lower colonisation and higher $\mathrm{P}$ demand. Crop growth reduction due to $\mathrm{C}$ use by AM is often observed when no further benefit from AMF hyphal P uptake is obtainable (Graham and Eissenstat 1998; Kahiluoto et al. 2001; Ryan et al. 2005).

\section{Comparison with previous findings}

It was shown that the general opinion created especially by field studies that soil plant-available $\mathrm{P}$ is the main factor determining the response of $\mathrm{P}$ nutrition and growth of a particular plant genotype to formation of the AM symbiosis (e.g., Hayman 1982; Thingstrup et al. 1998; Mäder et al. 2000; Ryan et al. 2000; Kahiluoto et al. 2001; Ryan and Graham 2002) does not apply when comparing cropping systems with qualitative differences in nutrient regimes and consequent slight differences in crop rotations (with or without legumes). Previously, no evidence of a difference in the benefit from AM at equal P uptake of flax with suppressed mycorrhization between the cumulative $\mathrm{P}$ fertilisation rates $\left(0\right.$ vs. $\left.45 \mathrm{~kg} \mathrm{P}^{-1}\right)$ was recorded (Kahiluoto et al. 2001). In contrast, in this study where $\mathrm{N}$ and $\mathrm{K}$ supply varied along with $\mathrm{P}$, even between the fertilisation rates there were differ- ences in the AM contribution to $\mathrm{P}$ uptake and growth at an equal supply of plant-available $\mathrm{P}$ for flax.

Our results confirmed the indirect evidence reported by Kahiluoto et al. (2009) that the higher AM contribution to plant $\mathrm{P}$ uptake and growth in the lowinput cropping system involving a qualitatively different nutrient regime, in comparison with the conventional cropping system, cannot be achieved in the conventional system through reducing the fertiliser application rate. There is evidently a qualitative difference between the two cropping systems in nutrient dynamics in terms of favouring and relying on AM. This finding questions the contrary conclusion of Ryan and Ash (1999) based on indirect observations of colonisation and crop performance only.

In agreement with Kahiluoto (2000) and Mäder et al. (2000), the main impacts of management on contribution of AM to plant performance seemed to be mediated through soil and plant partners, while long-term changes in the AMF community would have less importance. However, as Ryan and Graham (2002) have also stated, all the factors involved in determining the degree of benefit from AM in the cropping systems in the field may not yet be fully understood.

\section{Conclusions}

In contrast to the current general opinion, plantavailable P supply was shown not to be the major factor determining the AM contribution to plant $\mathrm{P}$ uptake and growth in cropping systems. There are important factors other than plant $\mathrm{P}$ availability that result in differences in AM contribution to the performance of particular crop genotypes among contrasting management systems. Based on indirect evidence, differences in nutrient pools, growth-limiting factors such as $\mathrm{N}$ supply, and phytotoxicity to AMF hyphae play a role in determining the benefit derived from AM in the management systems. It is improbable that differences in the AMF communities are of major importance. The differences in the benefit from AM among the systems were, even at equal $\mathrm{P}$ availability to plants with suppressed AM, similar to those assessed at the P status of the systems in the field. The benefit was greater in the low-input than in the conventional cropping system, irrespective of the fertilisation rate but most obviously with composting. The rate of colonisation at equal plant availability of $\mathrm{P}$ 
coincided with the differences in the benefit from AM to flax, but not to the more heavily colonised clover. It was also shown that $\mathrm{P}$ responses of AM need to be considered at equal $\mathrm{P}$ uptake rates by plants with suppressed AM. The findings of the present study suggest that qualitative differences rather than nutrient intensity determine the potential to rely on AM in plant $\mathrm{P}$ nutrition in contrasting cropping systems.

Open Access This article is distributed under the terms of the Creative Commons Attribution Noncommercial License which permits any noncommercial use, distribution, and reproduction in any medium, provided the original author(s) and source are credited.

\section{References}

Abbott LK, Robson AD (1984) The effect of mycorrhizae on plant growth. In: Powell CL, Bagyaraj DJ (eds) VA mycorrhiza. CRC, Boca Raton, pp 113-130

Alvarez-Santiago SA, García-Oliva F, Varela L (1996) Analysis of vesicular-arbuscular mycorrhizal colonization data with a logistic regression model. Mycorrhiza 6:197-200

Aura E (1978) Determination of available soil phosphorus by chemical methods. J Scient Agric Soc Finl 50:305-316

Bolan NS, Robson AD, Barrow NJ (1987) Effects of vesiculararbuscular mycorrhiza on the availability of iron phosphates to plants. P1 Soil 99:401-410

Burleigh SH, Cavagnaro T, Jakobsen I (2002) Functional diversity of arbuscular mycorrhizas extends to the expression of plant genes involved in $\mathrm{P}$ nutrition. $\mathrm{J}$ Exp Bot 374:1593-1601

Cameron DD (2010) Arbuscular mycorrhizal fungi as (agro) ecosystem engineers. Plant Soil 333:1-5. doi:10.1007/ s11104-010-0361-y

de Bertoldi M, Vallini G, Pera A (1983) The biology of composting: a review. Waste Manag Res 1:157-176

Dekkers TBM, van der Werff PA (2001) Mutualistic functioning of indigenous arbuscular mycorrhizae in spring barley and winter wheat after cessation of long-term phosphate fertilization. Mycorrhiza 10:195-201

de Miranda JCC, Harris PJ (1994) Effects of soil phosphorus on spore germination and hyphal growth of arbuscular mycorrhizal fungi. New Phytol 128:103-108

Fitter AH, Helgason T, Hodge A (2011) Nutritional exchanges in the arbuscular mycorrhizal symbiosis: implications for sustainable agriculture. Trends Cell Biol 25:68-72

Fliessbach A, Oberholzer HR, Gunst L, Mäder P (2007) Soil organic matter and biological soil quality indicators after 21 years of organic and conventional farming. Agric Ecosys Environ 118:273-284

Gange AC, Ayres RL (1999) On the relation between arbuscular mycorrhizal colonisation and plant 'benefit'. Oikos 87:615621

Gilbert N (2009) The disappearing nutrient. Nature 461:716-718
Giovannetti M, Mosse B (1980) An evaluation of techniques for measuring vesicular-arbuscular mycorrhizal infection in roots. New Phytol 84:489-500

Gosling P, Hodge A, Goodlass G, Bending GD (2006) Arbuscular mycorrhizal fungi and organic farming. Agric Ecosyst Environ 113:17-35

Grace C, Stribley DP (1991) A safer procedure for routine staining of vesicular mycorrhizal fungi. Mycol Res 95:1160-1162

Graham JH, Eissenstat DM (1998) Field evidence for the carbon cost of citrus mycorrhizas. New Phytol 140:103-110

Hartikainen H (1982) Water soluble phosphorus in Finnish mineral soils and its dependence on soil properties. J Sci Agric Soc Finl 54:89-98

Hartikainen H, Karppinen M, Uusitalo R (2006) Maan fosforivarat ja niiden käyttökelpoisuus. In: Alakukku L (ed) Maaperän prosessit: pellon kunnon ja ympäristönhoidon perusta. Maa-ja elintarviketalous 82. Maa-ja elintarviketalouden tutkimuskeskus pp 12-22

Hayman DS (1982) Influence of soils and fertility on activity and survival of vesicular-arbuscular mycorrhizal fungi. Phytopathol 72:1119-1125

Hodge A, Campbell CD, Fitter AH (2001) An arbuscular mycorrhizal fungus accelerates decomposition and acquires nitrogen directly from organic material. Nature 413:297-299

Huang C-YL, Schulte EE (1985) Digestion of plant tissue for analysis by ICP emission spectroscopy. Commun Soil Sci Plant Anal 16:943-958

Johnson NC (1993) Can fertilization of soil select less mutualistic mycorrhizae? Ecol Applic 3:749-757

Kahiluoto H (2000) A systems approach to the management of arbuscular mycorrhiza-Bioassay and study of the impact of phosphorus supply. Dissertation, University of Helsinki

Kahiluoto H, Vestberg M (1998) The effect of arbuscular mycorrhiza on biomass production and phosphorus uptake from sparingly soluble sources by leek (Allium porrum L.) in Finnish field soils. Biol Agric Hortic 16:65-85

Kahiluoto H, Vestberg M (2000) Creation of a nonmycorrhizal control for a bioassay of AM effectiveness 2. Benomyl application and soil sampling time. Mycorrhiza 9:259-270

Kahiluoto H, Ketoja E, Vestberg M (2000a) Promotion of utilization of arbuscular mycorrhiza through reduced $\mathrm{P}$ fertilization 1 . Bioassays in a growth chamber. P1 Soil 227:191-206

Kahiluoto H, Ketoja E, Vestberg M (2000b) Creation of a nonmycorrhizal control for a bioassay of AM effectiveness 1 . Comparison of methods. Mycorrhiza 9:241-258

Kahiluoto H, Ketoja E, Vestberg M, Saarela I (2001) Promotion of utilization of arbuscular mycorrhiza through reduced $\mathrm{P}$ fertilisation 2. Field studies. P1 Soil 23:65-79

Kahiluoto H, Ketoja E, Vestberg M (2009) Contribution of arbuscular mycorrhiza to soil quality in contrasting cropping systems. Agric Ecosyst Environ 134:36-45

Kenward MG, Roger JH (1997) Small sample inference for fixed effects from restricted maximum likelihood. Biometrics 53:983-997

Littell RC, Milliken GA, Stroup WW, Wolfinger RD, Schabenberger O (2006) SAS ${ }^{\circledR}$ for mixed models, 2nd edn. SAS Insitute Inc, Cary 
Mäder P, Edenhofer S, Boller T, Wiemken A, Niggli U (2000) Arbuscular mycorrhizae in a long-term field trial comparing low-input (organic, biological) and high-input (conventional) farming systems in a crop rotation. Biol Fertil Soils 31:150156

Mäder P, Fliessbach A, Dubois D, Gunst L, Jossi W, Widmer F, Oberson A, Frossard E, Oehl F, Wiemken A, Gattinger A, Niggli U (2006) The DOK experiment (Switzerland). In: Raupp J, Pekrun C, Oltmanns M, Köpke U (eds) Longterm field experiments in organic farming. ISOFAR Sci Series, Berlin, pp 41-58

Marschner H, Dell B (1994) Nutrient uptake in mycorrhizal symbiosis. Plant Soil 159:89-102

Molenberghs G, Verbeke G (2005) Models for discrete longitudinal data. Springer, New York

Morton JB (1990) Species and clones of arbuscular mycorrhizal fungi (Glomales, Zygomycetes): their role in macro- and micro-evolutionary processes. Mycotaxon $37: 493-515$

Mosse B, Stribley DP, LeTacon F (1981) Ecology of mycorrhizas and mycorrhizal fungi. In: Alexander M (ed) Advances in microbial ecology. USA, New York, pp 137-210

Munkvold L, Kjøller R, Vestberg M, Rosendahl S, Jakobsen I (2004) High functional diversity within species of arbuscular mycorrhizal fungi. New Phytol 164:357-364

Olsen SR, Watanabe FS, Cole CV (1960) Effect of sodium bicarbonate on the solubility of phosphorus in calcareous soils. Soil Sci 89:288-291

van der Paauw F (1971) An effective water extraction method for the determination of plant-available soil phosphorus. Pl Soil 34:467-481

Plenchette C, Clermont-Dauphin C, Meynard JM, Fortin JA (2005) Managing arbuscular mycorrhizal fungi in cropping systems. Can J Plant Sci 85:31-40

Ravnskov S, Jakobsen I (1995) Functional compatibility in arbuscular mycorrhizas measured as hyphal P transport to the plant. New Phytol 129:611-618

Ryan M, Ash J (1999) Effects of phosphorus and nitrogen on growth of pasture plants and VAM fungi in SE Australian soils with contrasting fertiliser histories (conventional and biodynamic). Agric Ecosys Environ 73:51-62

Ryan MH, Graham JH (2002) Is there a role for arbuscular mycorrhizal fungi in production agriculture? Pl Soil 244:263-271

Ryan MH, Angus JF (2003) Arbuscular mycorrhizae in wheat and field pea crops on a low $\mathrm{P}$ soil:increased Zn-uptake but no increase in P-uptake or yield. Pl Soil 250:225-239

Ryan MH, Chilvers GA, Dumaresq DC (1994) Colonization of wheat by VA-mycorrhizal fungi was found to be higher on a farm managed in an organic manner than on a conventional neighbour. P1 Soil 160:33-40
Ryan MH, Smal DR, Ash JE (2000) Phosphorus controls the level of colonisation by arbuscular mycorrhizal fungi in conventional and biodynamic irrigated dairy pastures. Austr J Exp Agric 40:663-670

Ryan MH, Norton RM, Kirkegaard JA, McCormick KM, Knights SE, Angus JF (2002) Increasing mycorrhizal colonisation does not improve growth and nutrition of wheat on Vertosols in south-eastern Australia. Aust J Agric Res 53:1173-1181

Ryan MH, van Herwaarden AF, Angus JF, Kirkegaard JA (2005) Reduced growth of autumn-sown wheat in a low-P soil is associated with high colonisation by arbuscular mycorrhizal fungi. Pl Soil 270:275-286

Sanders FE (1975) The effect of foliar-applied phosphate on the mycorrhizal infections of onion roots. In: Sanders FE, Mosse B, Tinker PB (eds) Endomycorrhizas. Academic, London, pp 261-276

Schofield RK (1955) Can a precise meaning be given to 'available' soil phosphorus. Soils Fert 28:373-375

Scullion J, Eason WR, Scott EP (1998) The effectivity of arbuscular mycorrhizal fungi from high input conventional and organic grassland and grass-arable rotations. Pl Soil 204:243-254

Sibbesen E (1983) Phosphate soil tests and their suitability to assess the phosphate status of soil. J Sci Food Agr 34:1368-1374. doi:10.1002/jsfa.2740341209

Smith SE, Smith FA, Jakobsen I (2004) Functional diversity in arbuscular mycorrhizal (AM) symbioses: the contribution of the mycorrhizal P uptake pathway is not correlated with mycorrhizal responses in growth or total $\mathrm{P}$ uptake. New Phytol 162:511-524

Sylvia DM, Schenck NC (1983) Application of superphosphate to mycorrhizal plants stimulates sporulation of phosphorustolerant vesicular-arbuscular mycorrhizal fungi. New Phytol 95:655-661

Sylvia DM, Neal LH (1990) Nitrogen affects the phosphorus response of VA mycorrhiza. New Phytol 115:303-310

Thingstrup I, Rubaek G, Sibbesen E, Jakobsen I (1998) Flax (Linum usitatissimum L.) depends on arbuscular mycorrhizal fungi for growth and $\mathrm{P}$ uptake at intermediate but not high soil P levels in the field. P1 Soil 203:37-46

Thingstrup I, Kahiluoto H, Jakobsen I (2000) Phosphate transport by hyphae of field communities of arbuscular mycorrhizal fungi at two levels of P fertilization. Pl Soil 221:181-187

Tinker PB, Nye PH (2000) Solute movement in the rhizosphere. UK, Oxford University Press, Oxford

Vestberg M, Kahiluoto H, Wallius E (2011) Arbuscular mycorrhizal fungal diversity and species dominance in a temperate soil with long-term conventional and low-input cropping systems. Mycorrhiza 21:351-361. doi:10.1007/ s00572-010-0346-y 